\title{
Classifying Pacific islands
}

\author{
Patrick D. Nunn ${ }^{1 *} \mathbb{D}$, Lalit Kumar ${ }^{2}$, Ian Eliot ${ }^{3,4}$ and Roger F. McLean ${ }^{5}$
}

\begin{abstract}
An earth-science-based classification of islands within the Pacific Basin resulted from the preparation of a database describing the location, area, and type of 1779 islands, where island type is determined as a function of the prevailing lithology and maximum elevation of each island, with an island defined as a discrete landmass composed of a contiguous land area $\geq 1$ ha $\left(0.01 \mathrm{~km}^{2}\right)$ above mean high-water level. Reefs lacking islands and short-lived ( $<20$ years) transient islands are not included. The principal aim of the classification is to assess the spatial diversity of the geologic and geomorphic attributes of Pacific islands. It is intended to be valid at a regional scale and based on two attributes: five types of lithology (volcanic, limestone, composite, continental, surficial) and a distinction between high and low islands. These attributes yielded eight island types: volcanic high and low islands; limestone high and low islands; composite high and low islands; reef (including all unconsolidated) islands; and continental islands. Most common are reef islands (36\%) and volcanic high islands (31\%), whereas the least common are composite low islands (1\%). Continental islands, 18 of the 1779 islands examined, are not included in maps showing the distribution of island attributes and types. Rationale for the spatial distributions of the various island attributes is drawn from the available literature and canvassed in the text. With exception of the few continental islands, the distribution of island types is broadly interpretable from the proximity of island-forming processes. It is anticipated the classification will become the basis for more focused investigation of spatial variability of the climate and ocean setting as well as the biological attributes of Pacific islands. It may also be used in spatial assessments of second-order phenomena associated with the islands, such as their vulnerability to various disasters, coastal erosion, or ocean pollution as well as human populations, built infrastructure and natural resources.
\end{abstract}

\section{Introduction}

As the management of human systems has become more globalized, so the need to effectively capture environmental diversity at global and regional scales has increased. Spanning almost one-third of the earth's surface, the Pacific presents a daunting challenge to anyone seeking to generalize about it, whether this refers to its geology, its ocean, its islands, or the peoples who inhabit them. In the past, perceptions of uniformity or emptiness within the Pacific encouraged generalization (Köppen 1936; Ward 1989) and even today, when the diversity of its natural environment is almost universally acknowledged, there remains a need for informed generalization for particular purposes (e.g., Ellison 2009; Dickinson 2001; Mueller-Dombois and Fosberg 1998; Neall and Trewick 2008; Richardson and Richardson 1986).

\footnotetext{
*Correspondence: pnunn@usc.edu.au

${ }^{1}$ University of the Sunshine Coast, Maroochydore, QLD, Australia Full list of author information is available at the end of the article
}

Compared to most inhabited parts of the earth's surface, the Pacific Basin bounded by continental margins is different in land areas that are comparatively small and isolated from one another and from the Basin rim; land totals around $0.34 \%$ of the area of the Pacific Basin. The number of people occupying Pacific islands is approximately 10.8 million, some $0.15 \%$ of the earth's population. These two attributes-comparatively small land area and small population size-have inevitably led to the marginalization of the Pacific islands region in many global datasets. Marginalization invariably encourages generalization and it is clear that Pacific islands and their inhabitants have not been well served by such generalizations in the past and would not be served well by them in the future, particularly as the pace of both natural and societal change accelerates (Crocombe 2001; Connell 2010, 2011; Nunn 2013).

This situation is redressed here by providing an earthscience-based classification for islands in the Pacific Basin

\section{包 Springer}

(c) 2016 Nunn et al. This article is distributed under the terms of the Creative Commons Attribution 4.0 International License (http://creativecommons.org/licenses/by/4.0/), which permits unrestricted use, distribution, and reproduction in any medium, provided you give appropriate credit to the original author(s) and the source, provide a link to the Creative Commons license, and indicate if changes were made. 
that is simple and readily applicable to a variety of purposes, while also capturing essential elements of island diversity. The principal aim of this classification is to capture the spatial diversity of the geologic and geomorphic attributes of islands in the Pacific region. This is then expected to become the basis for more focused descriptions of natural (biogeographic, ecological, pedologic) systems as well as second-order phenomena associated with Pacific islands, such as their exposure to climate change and natural disasters, as well as their vulnerability to coastal erosion or ocean pollution, for example.

This paper first explains the basis for classification, describes data sources and identifies the island types, and presents a first-order analysis of the database before discussing ways in which it might be applied.

\section{Basis for classification}

The region of interest for this classification is arbitrary yet usual in most discussions of islands within the Pacific Basin (Fig. 1). The outer boundary is the continental Pacific rim, comprising the west coasts of the Americas, the east coasts of Asia (including Japan), Australia and
New Zealand, as well as the Pacific coast of Antarctica. The defined region includes the independent countries of Cook Islands, Federated States of Micronesia, Fiji, Kiribati, Marshall Islands, Nauru, Niue, Palau, Papua New Guinea, Samoa, Solomon Islands, Tokelau, Tonga, Tuvalu, Vanuatu; the territories of American Samoa, French Polynesia, New Caledonia, Wallis, and Futuna; the commonwealth of the Northern Marianas Islands; the State of Hawaii; the US-administered islands in the central Pacific; the Galapagos islands (Ecuador); and the Chile-administered islands in the southeast Pacific. A summary of the islands included in the database is given in Table 1.

Islands that are clearly part of continents and/or are adjacent to the rim are not included; for ease of application, nations have not been subdivided into islands and non-islands except in rare instances. Islands in Indonesia, Japan, and the Philippines are excluded, largely because most have a peri-continental location and origin, whereas the islands of Papua New Guinea (including the large island of New Guinea) are included because they are mostly of oceanic origin; note that because it skews the

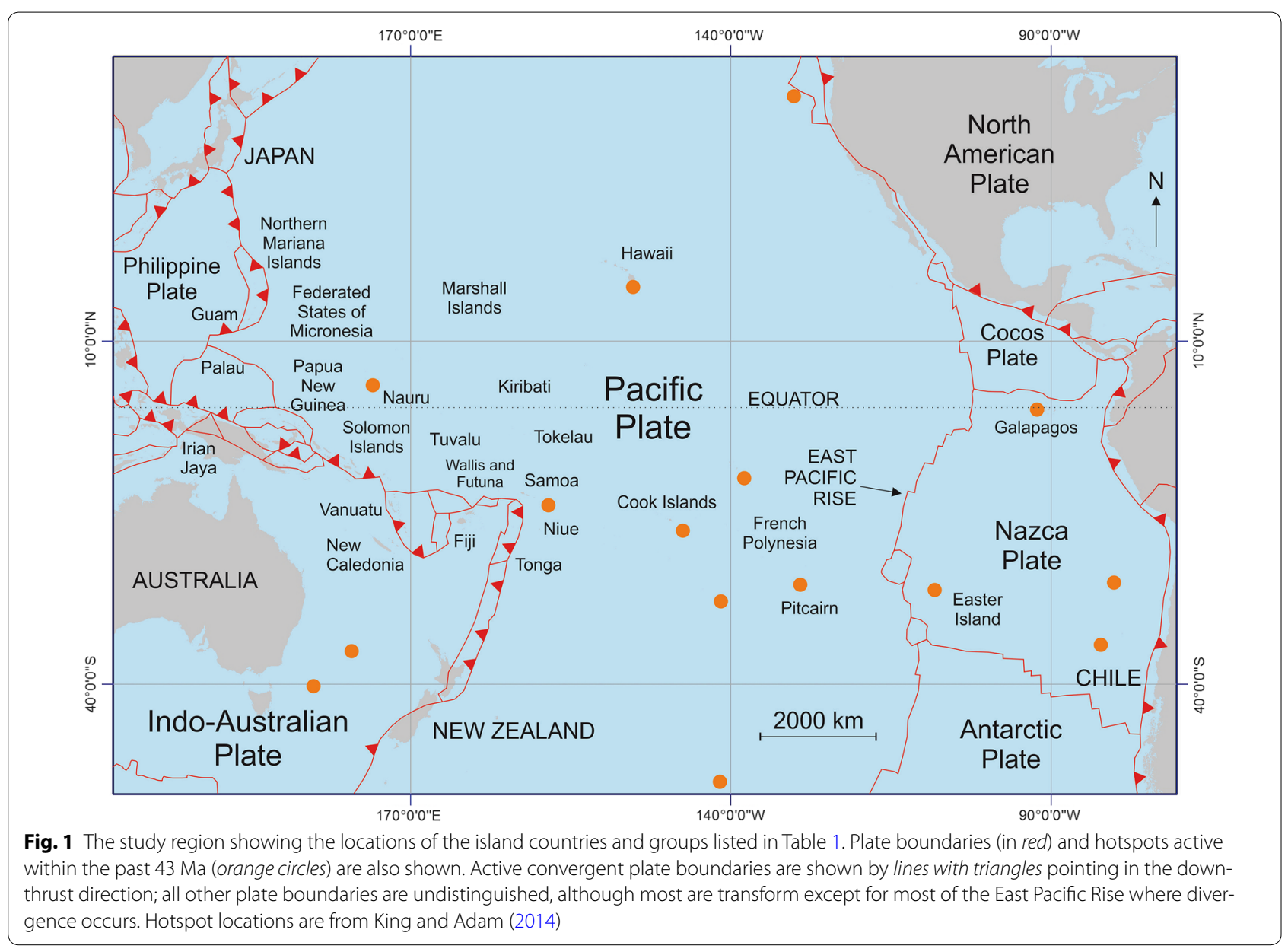


Table 1 Summary of key data in island database

\begin{tabular}{|c|c|c|c|c|}
\hline Country/group of islands & $\begin{array}{l}\text { Number } \\
\text { of islands }\end{array}$ & $\begin{array}{l}\text { Total area } \\
\text { of islands }\left(\mathbf{k m}^{2}\right)\end{array}$ & $\begin{array}{l}\text { Average island } \\
\text { area }\left(\mathrm{km}^{2}\right)\end{array}$ & $\begin{array}{l}\text { Average island } \\
\text { maximum elevation }(\mathrm{m})\end{array}$ \\
\hline American Samoa & 7 & 222 & 32 & 396 \\
\hline Chilean islands (eastern Pacific) & 2 & 215 & 108 & 269 \\
\hline Cook Islands & 15 & 297 & 20 & 73 \\
\hline East Pacific outliers ${ }^{a}$ & 24 & 8236 & 343 & 509 \\
\hline Federated States of Micronesia & 127 & 799 & 6 & 45 \\
\hline Fiji & 211 & 20,857 & 99 & 134 \\
\hline French Polynesia & 125 & 3939 & 31 & 154 \\
\hline Guam & 1 & 588 & 588 & 400 \\
\hline Hawaii & 16 & 19,121 & 1195 & 869 \\
\hline Kiribati & 33 & 995 & $30^{b}$ & 6 \\
\hline Marshall Islands & 34 & 286 & $8^{b}$ & 3 \\
\hline Nauru & 1 & 23 & 23 & 71 \\
\hline New Caledonia & 29 & 21,613 & 745 & 121 \\
\hline Niue & 1 & 298 & 298 & 60 \\
\hline Northern Mariana islands & 16 & 537 & 34 & 444 \\
\hline Palau & 33 & 495 & 15 & 58 \\
\hline Papua New Guineac & 437 & 67,754 & 155 & 135 \\
\hline Pitcairn islands & 4 & 54 & 13 & 97 \\
\hline Samoa & 7 & 3046 & 435 & 504 \\
\hline Solomon Islands & 415 & 29,675 & 72 & 88 \\
\hline Tokelau & 3 & 16 & $5^{b}$ & 5 \\
\hline Tonga & 124 & 847 & 7 & 56 \\
\hline Tuvalu & 10 & 44 & $4^{b}$ & 4 \\
\hline US-administered islands (central Pacific) & 8 & 37 & 5 & 5 \\
\hline Vanuatu & 81 & 13,526 & 167 & 330 \\
\hline Wallis and Futuna & 14 & 190 & 14 & 94 \\
\hline Total & 1778 & $1,93,712$ & 171 & 190 \\
\hline
\end{tabular}

Note that the island of New Guinea is excluded from the data analysis in this table because of its great size which skews the analysis

a This group is comprised mostly of the Galapagos islands, politically part of Ecuador

b Average island areas for these atoll countries are overestimates as they are based on polygons that subsume multiple islands (see text)

c Note that the large island of New Guinea is excluded from this analysis because it is shared between Papua New Guinea and Indonesia

data analysis, the island of New Guinea is excluded from the analysis in Table 1. The continental-outlier islands of New Caledonia (southwest Pacific) are also included because they are located within the Pacific Basin and surrounded by oceanic crust.

A fundamental question for any discussion about the common characteristics of islands is "what is an island?". For this classification, which treats only Pacific islands, the answer to that question is easier than for global surveys (Fairbridge 1968; Grigor'yev 1971; Kaplin 1981; Nunn 1994) because the area of interest (the Pacific Basin) is geographically bounded. All discrete landmasses within this area that comprise above mean highwater level contiguous areas of land $\geq 1 \mathrm{ha}\left(0.01 \mathrm{~km}^{2}\right)$ are considered islands. This includes some as large as New Guinea $\left(\sim 786,000 \mathrm{~km}^{2}\right)$ to numerous others, mostly off the shores of larger islands, that are close to the lower size limit. Reefs lacking islands are not considered as islands, although they are in some island lists [e.g., Motteler (2006)]. Transient islands, such as those that may appear or disappear during storms, are not included unless they had existed continuously for more than 20 years at the time of data collection in 2013. Likewise islands that formerly existed, perhaps at times of lower sea level in the past, are not included. The data used in this paper represent a snapshot of the situation in the Pacific around the start of the 21st century.

The purpose of any classification of natural phenomena (such as islands) is the key to its structure. Given that our classification seeks to capture the diversity of physi$\mathrm{cal}$ and natural attributes of islands, the most appropriate classification is one based at its highest level on lithology 
and elevation. The choice of these variables reflects the dominant controls on a broad range of characteristics of Pacific islands, including their erodability and resistance, their drainage (surficial and subterranean), and their landscapes (and major landscape processes). It was decided not to include a measure of climate (because this is implicit in elevation) nor any measure of exposure to particular natural hazards (like volcanic eruptions, earthquakes, tsunamis, tropical cyclones) given that this is highly variable both spatially and temporally within the Pacific Basin and therefore more suited to a second-order layer of classification.

\section{An island database and data sources}

A database of islands in the Pacific Basin $(n=1779)$, summarized in Table 1 and available as Additional File 1 , refers to all islands $\geq 1$ ha $\left(0.01 \mathrm{~km}^{2}\right)$ in area in the study region. For each island, data on lithology and elevation were acquired, allowing island type to be identified. Reef islands scattered along an elongate reef are counted as one island rather than several islands because such islands are often transient, changing shape and size over decadal periods, sometimes connected to others (at low tide or by causeways), sometimes severed by subtidal channels (after storms).

Diagnostic data including location and shape for each island were obtained from the world vector shorelines (WVS) digital data file which contains shorelines along the ocean-land interface (Soluri and Woodson 1990). At a scale of 1:250,000, the WVS is a US Defense Mapping Agency product that supports geographical information systems at regional and global scales. Since the WVS was created at very broad scales from satellite imagery, there will inevitably be slight distortions in the positional accuracy and shapes of the islands, although for the spatial scale and resolution of this work, this data source was deemed acceptable.

In the following subsections, sources of key data (island locations, names, elevations, areas, lithologies) for these two databases are discussed separately.

\section{Island locations}

In the island database, latitude and longitude were obtained from Google Earth for almost all islands, the cursor being placed over the center of an island and coordinates recorded. The advantage of this approach is its consistency and the resulting impossibility of islands overlapping in location. One disadvantage is that a single pair of coordinates does not say anything about the size or shape of a particular island or its proximity to nearest neighbors. This is less of a problem with islands (of any size) that are approximately circular in form but does pose challenges for those that are less uniformly shaped.
Many reef islands that form atolls, for example, are long sinuous entities and sometimes a degree of subjective judgement is needed to identify their approximate center. Sometimes, it is unclear whether two islands form a single continuous body or not; indeed, it is possible that they do at low tide (when people may be accustomed to walk from one to the other) but not at higher tide levels.

While having no reason to doubt the accuracy of the latitudes and longitudes reported in Google Earth for the vast majority of islands, each location was cross-checked for correctness against another source, usually a list of islands generated for a particular country or island group. In some cases, usually for smaller, more isolated island groups, the only source of earlier locational information found was a map, from which coordinates were read. For some smaller (typically more isolated) islands, no source of latitude and longitude other than Google Earth was readily available.

All that was sought from cross-checking was that the latitude and longitude recorded in Google Earth were approximately the same as that recorded previously. This was an important check on whether the correct (named) island had been identified in Google Earth. Where minor differences were found in the coordinates for a particular island, it was assumed that those in Google Earth were superior. Often a disparity was found to arise because coordinates from Google Earth were centered within a particular island, whereas coordinates from other (earlier) sources for an island were often those of a particular place of interest (like a coastal settlement) within that island not its geographical center.

The latitude and longitude information thus recorded were then converted into a GIS shapefile using the World Geodetic System 1984 (WGS84) coordinate system. This file was then overlaid on a WVS polygon file to allow island names to be assigned to each of the polygons. Since the WVS map layer is created at a very broad scale and coarse-scale satellite imagery is used, there were inevitably minor inaccuracies in positions and shapes of islands. With a world base map provided by ESRI as a background, individual WVS polygons were moved where necessary to align with this base map. Where the WVS polygons were not a good match with the actual island shape or where polygons were missing, especially for smaller islands, new polygons were digitized from the background base map at a scale of 1:20,000. These polygons were more accurate than those obtained from the WVS.

\section{Island names}

The main reference for island names was Motteler (2006). This text is widely regarded as the standard listing of islands in particular Pacific island groups, although it is 
incomplete. In some island groups, the names of even sizeable islands are not listed, while others may be spelled in ways that are clearly not those preferred by the modern nation of which the particular island is part. In some island groups, the names of even the smallest islandsoften uninhabited rocks of less than 0.01 ha in area-are given, while in others they are omitted. Many reefs (not reef islands) are also included in the Motteler list but were omitted from the database for this paper. The prevalence of European names (and earlier European names) for islands rather than current (and previous) local/vernacular names is a weakness of the Motteler list (2006); one source that was especially useful in rectifying this was Langdon (1978) who gives two gazetteers of equivalent and obsolete names for many islands. Despite such concerns, by and large, the Motteler text represents the most complete source of information about Pacific island names and is accompanied by a series of informative maps.

Google Earth and Google maps often provide island names, although these may be misplaced, especially with the smaller islands, or misspelled. It was found that Google Earth often confuses islands of the same name (or similar names) and as a result in some instances may place the names considerable distances from the islands to which they correctly refer. The use of photos (loaded by users without consistent quality control) in Google Earth is helpful but potentially a source of serious error both not only because (island) names are often wrong but also because the photos may be wrongly located, particularly in more isolated areas, less frequently visited by tourists. Other sources of locational information were obtained from various atlases, maps, and encyclopedias as well as a variety of internet sources, although these are not always reliable.

\section{Island lithologies}

Lithology is considered a primary basis for classification because it is fundamental to numerous physical-natural attributes of islands as well as their recent development through which it links to island-forming processes (Herzberg 2011; Walsh 1982). It is a major cause of diversity in the Pacific yet there are dangers in being too specific, given that few islands are effectively of just one lithology and that different lithologies sometimes have comparable attributes. For this reason and in order to make this classification as easy to use as possible, we distinguish five types of lithology-volcanic (igneous), limestone (calcareous and non-volcanic sedimentary), composite (less than $80 \%$ volcanic and less than $80 \%$ limestone), reef (unconsolidated sediment) islands, and continental (nonoceanic) islands.

Archival (library) sources of information about Pacific island lithology are too numerous to review here. Of the Pacific regional sources used, several were especially helpful for providing context (Gillespie and Clague 2009; Menard 1986; Neall and Trewick 2008; Nunn 1994, 1998b, 1999; Vacher and Quinn 1997; Wiens 1962), while at a subregional level, a wider range of publications proved useful (including Anthony 2004; Bonatti et al. 1977; Bonvallot et al. 1993; Brocher 1985; Coleman 1970; Dana 1875; Davis 1920; Derrick 1957; Dow 1977; Duncan and McDougall 1976; Greene and Wong 1988; Jost 1998; Keating and Bolton 1992; Macdonald et al. 1983; McBirney et al. 1969; Scholl and Vallier 1985; Tracey et al. 1964; Wood 1967).

There are also numerous sources of sub-national (island group) information about lithology available, usually in the form of academic publications (found in libraries but identified using Google Scholar) that describe the geology of a particular island or group of islands. While invariably focused on research questions requiring more than descriptions of island lithology, these are often included as background details and were extracted to include in the database.

Solely online sources of information about island lithology were used principally to confirm details obtained from library sources (see above). Online sources included photographs in Google Earth which, unless misplaced (see above), were sometimes able to provide good information about lithology. The most useful photographs were those off/from the island's coast which sometimes show the composition of cliffs or the form of the island itself, both of which aid in confirming its dominant lithology. While both volcanic and limestone islands have cliffs, those of the latter generally tend to be flattertopped and straighter-sided. The form of an emerged limestone island is generally marked by flat tabular surfaces (former reef surfaces) in stark contrast to the form of volcanic islands where flat surfaces are rarer and the topography is often dominated by peaks and valleys.

Supplementary online sources used were encyclopedias, generally Wikipedia, that not only gives accounts and photographs of particular islands, but also links to more formal and more reliable reference materials. The authors' own knowledge was used to verify lithologies of particular islands.

\section{Island elevations}

Elevation is also considered an important first-order classifier because it reflects aspects of lithology as well as recent island development, capturing both island building (including tectonics) and denudation. It is also a cause of significant diversity in the Pacific and it is suggested that a simple twofold distinction between high and low islands, separated by a $30-\mathrm{m}$ elevation above mean sea level, best captures this. The use of $30 \mathrm{~m}$ as the divider 
between high and low is arbitrary but in our experience best separates lower (less resistant, greater surface lowering) islands from higher (more resistant, less denuded) ones. Similar classificatory procedures have been used to separate younger (upstanding) volcanic islands from older (more denuded) ones (Menard 1983; Ramalho et al. 2013).

For the purposes of this project, the only information about elevation required for classification is whether or not the maximum elevation of a particular island is less than $30 \mathrm{~m}$ (above mean sea level) or not. This information is a crucial component of island type, and is obtainable using Google Earth but, after using this a few times, it became clear that errors in some instances were potentially large (there were apparent differences between the elevation at Point A in Google Earth and that on a topographic map of the island) and that it was not always straightforward to identify the highest point on a particular island with this tool. Thus, for the purposes of determining island maximum elevation, other (library, online, expert knowledge) sources of information (especially Dahl 1980; Karolle 1993; Lobban and Schefter 1997; Mueller-Dombois and Fosberg 1998; Rapaport 2013) were used with Google Earth providing corroboration only. The authors' own knowledge was used to verify maximum elevations of particular islands.

\section{Island areas}

Areas for islands were calculated directly from the polygon shapefile layer in a GIS as described in "Island locations" section. While published records of island areas exist, these commonly differ with reference to the same island. In addition, it is likely that some island areas stated as referring to single entities incorporate smaller offshore islands, so are unreliable. With these constraints in mind, published information about island area from various sources was used to confirm the automatically calculated areas for most islands in the database. We accept that areas of islands calculated from polygons generated from coarse-scale satellite imagery would have larger errors than those calculated from fine-scale topographical maps, yet for the broad-scale work undertaken in this research this level of inaccuracy was deemed acceptable. The areas calculated from the polygon shapefile were generally within the range of figures obtained for individual islands from different published sources. The calculation of all areas using the polygon shapefile ensured that whatever errors were present were consistent.

\section{Island types}

Using the data described in "An island database and data sources" section, we produce a classification of islands in the Pacific based on the lithology and elevation of each island. The classification involves eight categories, described below.

Volcanic high islands are those composed of at least 80 \% igneous rock types that rise to a maximum elevation of at least $30 \mathrm{~m}$ above mean sea level. In the Pacific, these island types are the commonest in those places where there is active (usually submarine) volcanism within $500 \mathrm{~km}$. Such places may be in the volcanic island arcs that develop above convergent plate boundaries or around mid-plate hotspots where magma reaches the ocean surface and builds chains of volcanic islands.

Volcanic low islands are those which are composed of at least $80 \%$ igneous rock types and rise to a maximum elevation of less than $30 \mathrm{~m}$ above mean sea level. In the Pacific, these island types are common not only where higher volcanic islands are found but also tend to occur farther away from contemporary sites of active volcanism. Along hotspot island chains, the highest islands are usually close to the hotspot itself while farther away, the volcanic islands (largely through subsidence) are generally lower. Elsewhere, once removed from the area in which volcanic islands form, such islands also subside and become reduced in elevation by subaerial erosion (Scott and Rotondo 1983).

Limestone high islands are those which are composed of at least $80 \%$ calcareous rock types and rise to a maximum elevation of at least $30 \mathrm{~m}$ above mean sea level. In the Pacific, these island types are commonest in those places where (tectonic) uplift has been occurring for several 100,000 years, most commonly as a result of one (oceanic) plate being pushed up over another as is usual along convergent plate boundaries. High limestone islands commonly develop along such forearcs. Elsewhere collision/compression of lithospheric plates may cause uplift of islands in places where subduction is not taking place.

Limestone low islands are those which are composed of at least $80 \%$ calcareous rock types and rise to a maximum elevation of less than $30 \mathrm{~m}$ above mean sea level. In the Pacific, these island types are common where high limestone islands are found (see above), the distinction often being largely attributable to the degree of net uplift that particular islands have experienced. Low limestone islands are also found in many places (not tectonically active) where reef islands are found (see below) and it is sometimes difficult to distinguish the two types. The low limestone islands tend to be significantly older and typically formed (in part at least) from reefs that were living around $6 \mathrm{~m}$ above present sea level during the Last Interglacial period, around 125,000 years ago and sometimes during earlier Quaternary interglacial periods. 
Reef islands are those which are composed of at least $80 \%$ unconsolidated sediments (derived from adjacent offshore/underwater areas) that have accumulated on a shallow flat (shoal), commonly biogenic (reefal) in origin. While sometimes confused with lower types of low limestone island (see above), reef islands tend to rise no more than $3 \mathrm{~m}$ above mean sea level and are characterized by shorelines that change position faster than those of other island types. Often reef islands are long and sinuous, accumulated on sub-circular (atoll) reefs that have grown up from the submerged flanks of a drowned volcanic island. Reef islands also develop on other types of reef (Stoddart et al. 1978). Of all the island types in this classification, reef islands are the most transient, many of those that exist today having formed only after sea level in the Pacific began falling from its Holocene maximum around 4000 years ago. Reef islands are widespread in the low-latitude Pacific, concentrated along atoll reefs in its equatorial central part.

Composite high islands are those which are composed of both less than $80 \%$ volcanic and less than $80 \%$ calcareous (limestone) rock types and rise to a maximum elevation of at least $30 \mathrm{~m}$ above mean sea level. In the Pacific, these island types are commonest in places where longterm subsidence (allowing thick reefs to develop around a volcanic island) has been interrupted by long-term uplift (causing those reefs to emerge) resulting in the formation of makatea islands (Nunn 1994). Other more diverse composite high islands occur around convergent plate boundaries, typically formed over long time periods by processes associated with alternating volcanism (along a volcanic island arc) and uplift (along a forearc).

Composite low islands are those which are composed of both less than $80 \%$ volcanic and less than $80 \%$ calcareous rock types and less than $80 \%$ unconsolidated sediments (forming reef islands) and rise to a maximum elevation of less than $30 \mathrm{~m}$ above mean sea level. In the Pacific, these island types are common where composite high islands are found, the difference often being that island-forming processes (volcanism and/or uplift) were less active and therefore produced a lower island. Also it is clear that such processes often produced composite high islands that are comparatively large surrounded by smaller islands, representing peripheral parts of the structure, that are lower.

Continental islands are those which are composed of at least $80 \%$ continental (not of oceanic origin) rocks. Given that these island types are so few within the study area and that almost all are above $30 \mathrm{~m}$ maximum elevation, this island type is not subdivided on the basis of elevation. Such islands are found exclusively in the New Caledonia group.

\section{Results: outcomes of classification}

Several primary attributes for each of 1779 islands in the Pacific Basin, namely island location, area and type, where type is determined by the dominant lithology and maximum elevation, were compiled in a database. These attributes were then used to produce maps of the Pacific at a broad scale to establish the spatial diversity of the geologic and geomorphic attributes of the islands. The maps were generated by representing each island in the database as a single point (Figs. 2, 3, 4, 5 and 6).

Islands are distributed unevenly throughout the Pacific Basin (Fig. 2), the most numerous being in the southwest quadrant and fewest in the northeast quadrant. They are clustered, mostly in linear patterns, yet there are vast tracts of landless ocean, especially in the eastern Pacific (approximately $140-100^{\circ} \mathrm{W}$ ) and in high-latitude areas.

Areas were determined for all islands in the database (Fig. 3). The map in Fig. 3 shows the distribution of islands by size, the key shows the proportion of islands in each size category. The distribution is dominated by small islands, with $67 \%<10 \mathrm{~km}^{2}$ and $44 \%<1 \mathrm{~km}^{2}$ in area. Large islands, those with an area $>100 \mathrm{~km}^{2}$, comprise approximately $6 \%$ of the 1779 islands in the database.

Five lithological types are recognized for Pacific islands: composite, continental, limestone, reef, and volcanic. Their spatial distribution is shown in Fig. 4 with proportions given in the key. Volcanic (39\%) and reef (36\%) lithologies are the most common; limestone (17\%) and composite $(7 \%)$ follow, islands with continental lithologies are few (1\%).

All islands in the database are classified as either high (maximum elevation of $30 \mathrm{~m}$ or higher) or low (maximum elevation $<30 \mathrm{~m}$ ), although five elevation categories have been identified for the purposes of discussion and are shown in Fig. 5. $45 \%$ of the islands are lower than $30 \mathrm{~m}$, with $27 \%$ less than $5 \mathrm{~m}$. In contrast, $26 \%$ are higher than $100 \mathrm{~m}$.

Island type is the combination of lithology and elevation and is regarded as the highest-level basis for meaningful classification of Pacific islands. The distribution of islands by type is shown in Fig. 6 with the key showing the proportions of each. Perhaps unsurprisingly, the most common types are reef islands (36\%) and volcanic high islands $(31 \%)$ and the least common are composite low islands (1\%). Continental islands, 18 of the 1779 islands examined, are not included in the classification.

\section{Discussion}

A rationale for the separate spatial distributions of island types and their attributes (Figs. 2, 3, 4, 5 and 6) is considered below with the distributions interpreted in the context of available information. Additionally, preliminary 


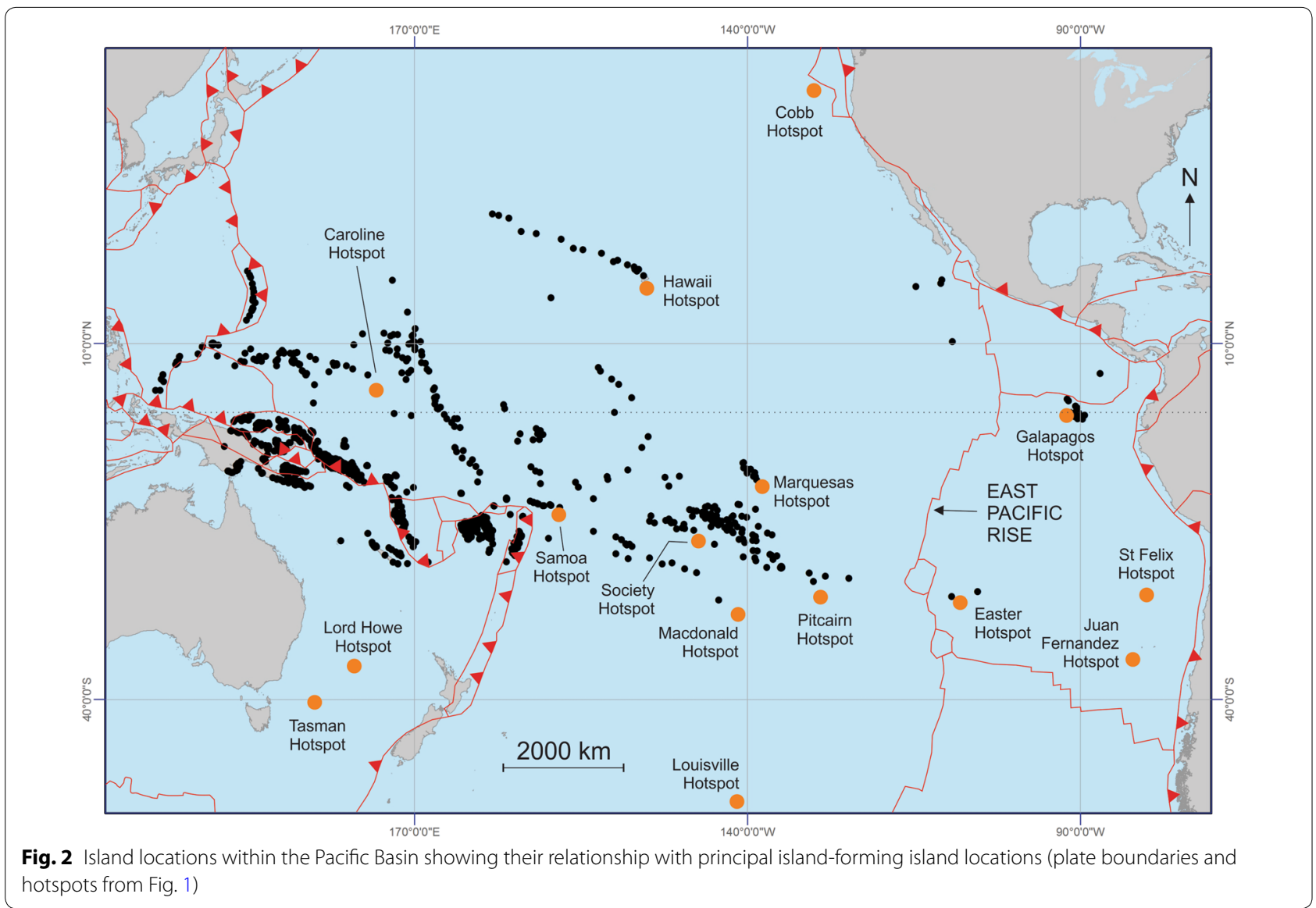

statistics describing the number of islands, their total and average area and average maximum elevation have been determined for each country or group of islands included in the database (see Table 1).

Those countries with the greatest number of islandsPapua New Guinea, Solomon Islands and Fiji-are countries with comparatively large populations, most of whom subsist from the land on which they reside. That these islands are also quite large $\left(>31 \mathrm{~km}^{2}\right)$ and high $(>88 \mathrm{~m})$ exemplifies the points that the larger an island, the more possibilities it generally presents for human livelihoods, and the higher the island, the more likely it is to receive sufficient rainfall for a diversity of human needs.

At the other end of the scale, generalization is less straightforward. There are several single island countries/ groups, most born from distinct political histories reinforced in some cases by relative geographical isolation. Examples include Nauru, which owes its independence to a history of phosphate extraction and indeed its phosphorites to its geographical isolation (the only landmass for roosting birds within a large area), and Niue, independent largely because of similar isolation which prevented it from becoming an obvious part of either Tonga (to the west) or the Cook Islands (to the east). Other islands countries/groups with comparatively few numbers (see Table 1) may also be artifacts of history as well as geographical isolation.

\section{Island locations}

The pattern of islands in the Pacific Basin can be broadly interpreted by the prevalence of (the most effective) island-forming processes in particular areas. The exceptions, which are not a central focus of this paper, are the continental islands in New Caledonia (SW Pacific) that represent emergent parts of a sliver of continental lithosphere that acquired its present oceanic location only following the opening of the Tasman Sea about $84 \mathrm{Ma}$ (Lafoy et al. 2005). All other Pacific islands originated as ocean-floor volcanoes, which means that the locations of most of them today can be linked to places where oceanfloor volcanism continues or where it ceased within the past few million years (Nunn 1999).

There are three principal geophysical situations in the Pacific Basin in which ocean-floor volcanism occurs (Frisch et al. 2011; Duncan and Richards 1991; Husson and Conrad 2012; Nunn 1994). The first is at a divergent 


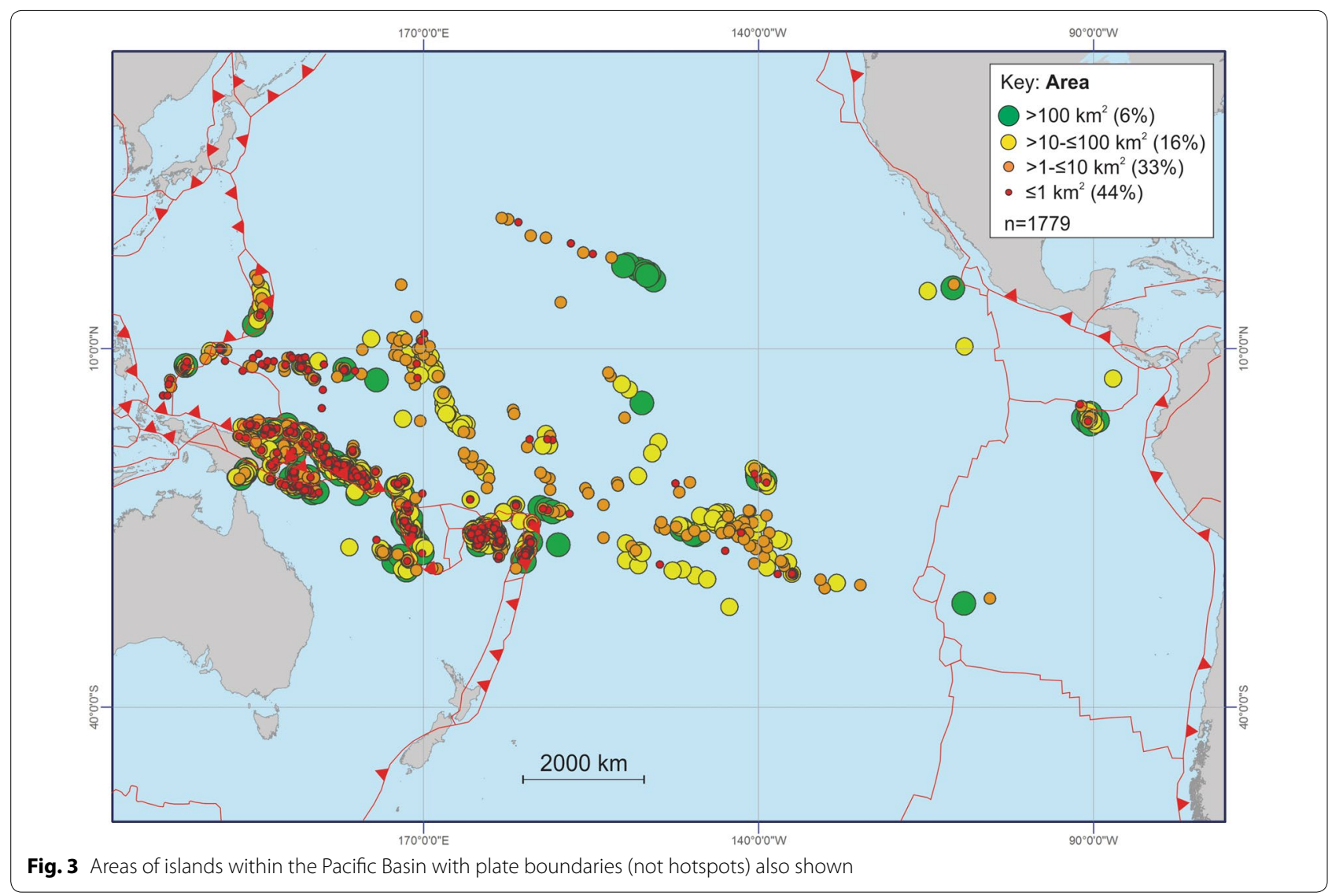

plate boundary (often a mid-ocean ridge) and involves magma rising up from the asthenosphere at places where the overlying lithosphere is fractured and diverging. The second is at a convergent plate boundary, above the place where a downthrust lithospheric plate is melting as a result of subduction. The third is in intraplate (mid-plate) situations where a (mantle) plume has penetrated through the lithosphere to create a hotspot, which is comparatively stationary relative to the movement of the lithospheric plate. In all three situations, island building is attributable to both extrusive volcanism and, often more importantly, to intrusion. While allowing for islands to have moved considerable distances since their time of origin, the simplest explanation for the locations of Pacific islands is, depending in which of the three geophysical situations they formed, their proximity to convergent plate boundaries or intraplate hotspots. Figure 2 shows the distribution of divergent and convergent plate boundaries and intraplate hotspots (active since $43 \mathrm{Ma}$ ) in the Pacific relative to the distribution of islands. Compared to other ocean basins, divergent plate boundaries (mid-ocean ridges or MOR) are less numerous in the Pacific, while convergent plate boundaries are more numerous and concentrated in the western Pacific.
It is apparent that there are very few islands close to divergent plate boundaries in the Pacific, largely because both the crests and (steep-sided) flanks of most midocean (or back-arc basin) ridges are in deep ocean. Following island formation at the crests, islands are generally carried into deeper water and often may not reach the surface until they cross a lithospheric swell, for instance, which may be thousands of kilometers from the plate boundary at which they originated. For this reason, divergent plate boundary islands are comparatively few and usually emergent only when other processes have contributed to their upgrowth. Examples from the Pacific Basin were once thought to include Easter Island, which is close to the mid-ocean ridge (MOR) named the East Pacific Rise, but no evidence of MOR basalts is found there (Ray et al. 2012). Better examples come from the back-arc basins in the western Pacific where small MORs have produced islands like Niuafo'ou (Tonga) and Mota Lava (Vanuatu) (Sorbadere et al. 2013; Tian et al. 2011).

Far more numerous in the Pacific (but not in other ocean basins) are islands formed at convergent plate boundaries. Such islands are invariably organized in linear or arcuate groups and have often not moved far from the places at which they formed. Such islands include 


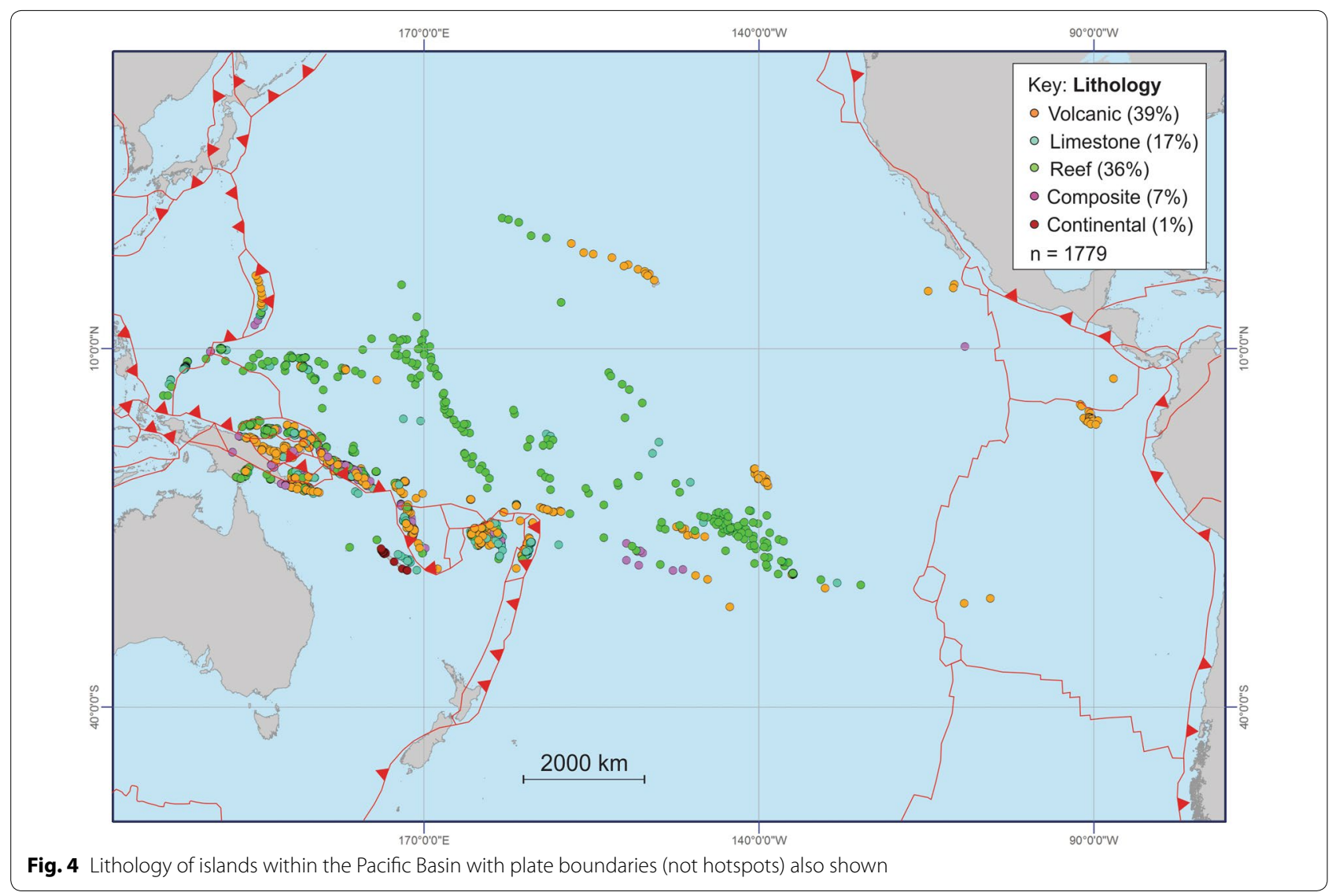

(volcanic) islands that form above the zones of subsurface magma accumulation, emerged (limestone) islands that form adjacent to the places (forearcs) where one plate is pushed beneath another, and (composite) islands that represent amalgams of the preceding types that are often found in remnant locations at a distance from contemporary subduction zones (Nunn 1994). In the southwest Pacific, the three types are geographically separated in Solomon Islands and Vanuatu (Greene and Wong 1988; Petterson et al. 1999). More common are en echelon lines of limestone (forearc) and volcanic islands running parallel to an adjacent trench axis, such as are found in Tonga and the Marianas islands (Nunn 1998b; Oakley et al. 2009). In their simplest expression, usually where subduction began only comparatively recently, a single line of young volcanic islands is found; examples are found in the Aleutian and Kurile groups in the northernmost Pacific as well as parts of Papua New Guinea (Prueher and Rea 2001; Silver et al. 2009).

Around $43 \mathrm{Ma}$ there was a major change in the direction in which the rigid Pacific plate was moving as a result of which the oldest hotspot island chains on this plate all exhibit a marked kink at this point. The best-documented example is the Hawaiian-Emperor island-seamount chain, which is believed to have been forming for at least the past 81 million years as a consequence of the Pacific Plate passing over a hotspot currently located just southwest of Hawai'i island (the Big island) at its southwest end (Ballmer et al. 2011). Most hotspot chains in the Pacific are younger. Those that have formed most islands include the Caroline, Marquesas, Macdonald, Samoa, and Society hotspot chains, all of which have been active within the past 1.2 million years (Clouard and Bonneville 2001; Wessel and Kroenke 2008). At such hotspots, a line of volcanic islands is produced by the movement of the lithospheric plate over a hotspot. Generally the further away, an island is from the hotspot, the more it has subsided so the older and smaller/lower it is, which explains why many of the oldest islands in the Hawaii-Emperor chain became atolls and finally (undersea) guyots (Nunn 1994).

There are a small number of often isolated islands in the Pacific whose origin does not readily fall into one of the categories discussed above. These include islands that rise from locally thickened oceanic crust, possibly terranes, such as those of Ontong Java (Solomon Islands) and Manihiki (Cook Islands) (Taylor 2006), and those that originated at complex plate boundaries, including plate triple junctions, such as Simbo and others in the 


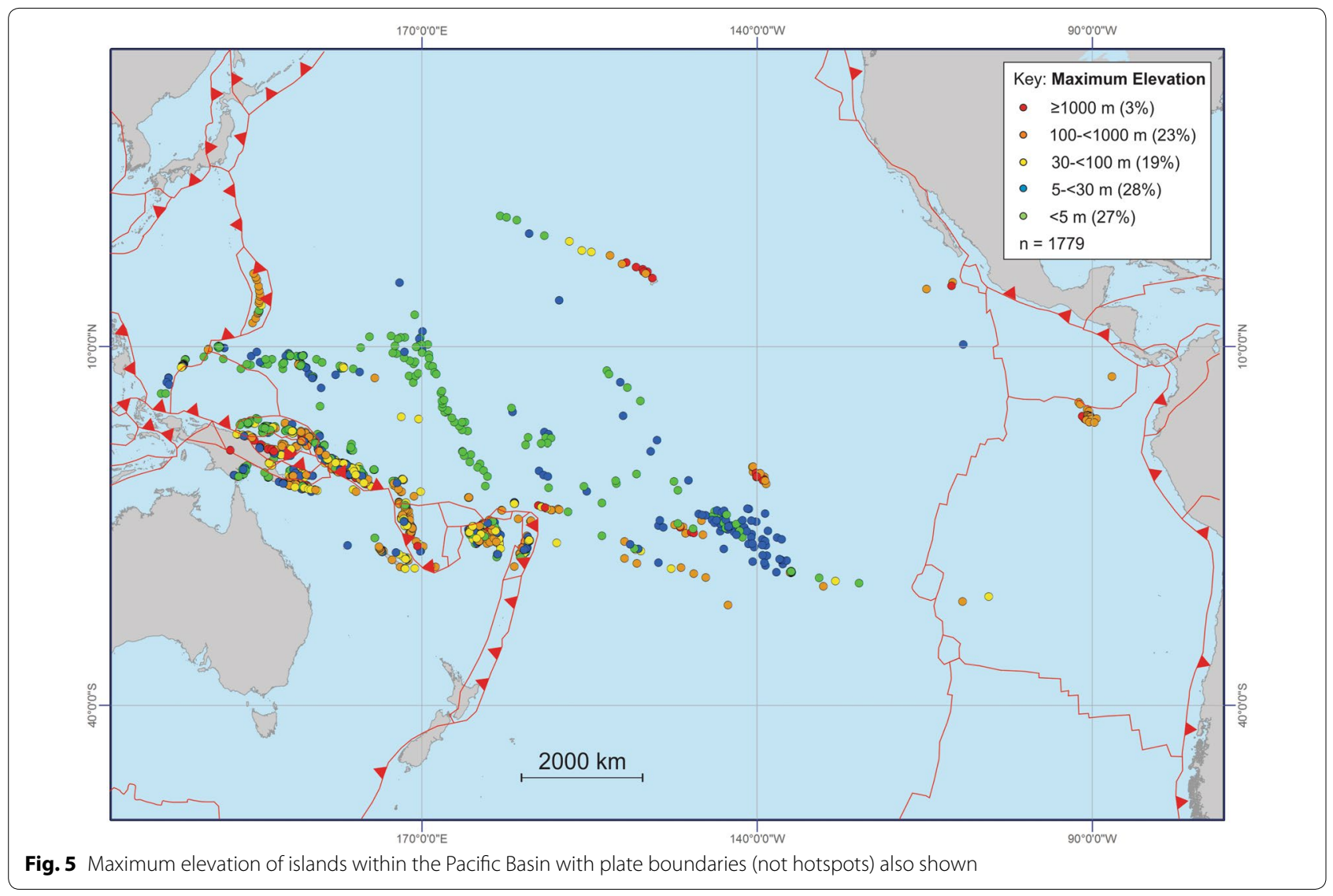

New Georgia group (Solomon Islands) (Crook and Taylor 1994) as well as the Galapagos islands (Smith et al. 2013).

It is also important to comment on the areas within the Pacific Basin from which islands are absent. Islands tend to be generally absent from higher latitudes $\left(>30^{\circ} \mathrm{N}\right.$ and $>30^{\circ} \mathrm{S}$ ) as well as from most areas around the East Pacific Rise. The absence of islands at higher latitudes in the Pacific can partly be explained by the cooling of oceansurface waters that prevent submerged islands continuing to have surface expression through the upgrowth of (atoll) reefs (Nunn 1994). This certainly explains discontinuities in linear island chains such as the Hawaiian group but is also a function of the relative inability of island-forming processes to create and sustain emergent islands (rather than seamounts and guyots) in such areas. For example, the southernmost hotspot shown in Fig. 2, the Louisville hotspot, has a comparatively low level of volcanic activity and has not generated significant lithospheric swells (Sleep 1990) which may be a prerequisite to island emergence in such situations.

The absence of islands in the northeast quadrant of the Pacific may be a result of the change in Pacific Plate motion that occurred $43 \mathrm{Ma}$, which has stretched westwards what would have been a much smaller islandfree area of ocean before this time.

The absence of islands around the region's major divergent plate boundary, the East Pacific Rise, is explainable by its steep undersea flanks and the likelihood that any islands formed in such places would soon get carried into deeper water.

\section{Island areas}

The dominance of smaller $\left(\leq 10 \mathrm{~km}^{2}\right.$ in area) islands in Fig. 3 can be explained in two ways. First, since the Last Glacial Maximum (LGM), when Pacific sea level was perhaps $120 \mathrm{~m}$ lower than today (Oba and Irino 2012), island coasts have been progressively drowned resulting in their fragmentation into smaller islands. This is suggested by the common situation where innumerable smaller islands are found close to the coast of larger ones, to which they were once joined. Instinctively this may be considered to have added to the number of islands in the Pacific since the LGM but, unless the number to have been completely submerged by subsequent sea-level rise is known, this cannot be demonstrated. The second reason is that once sea level stabilized in the Pacific, beginning around 


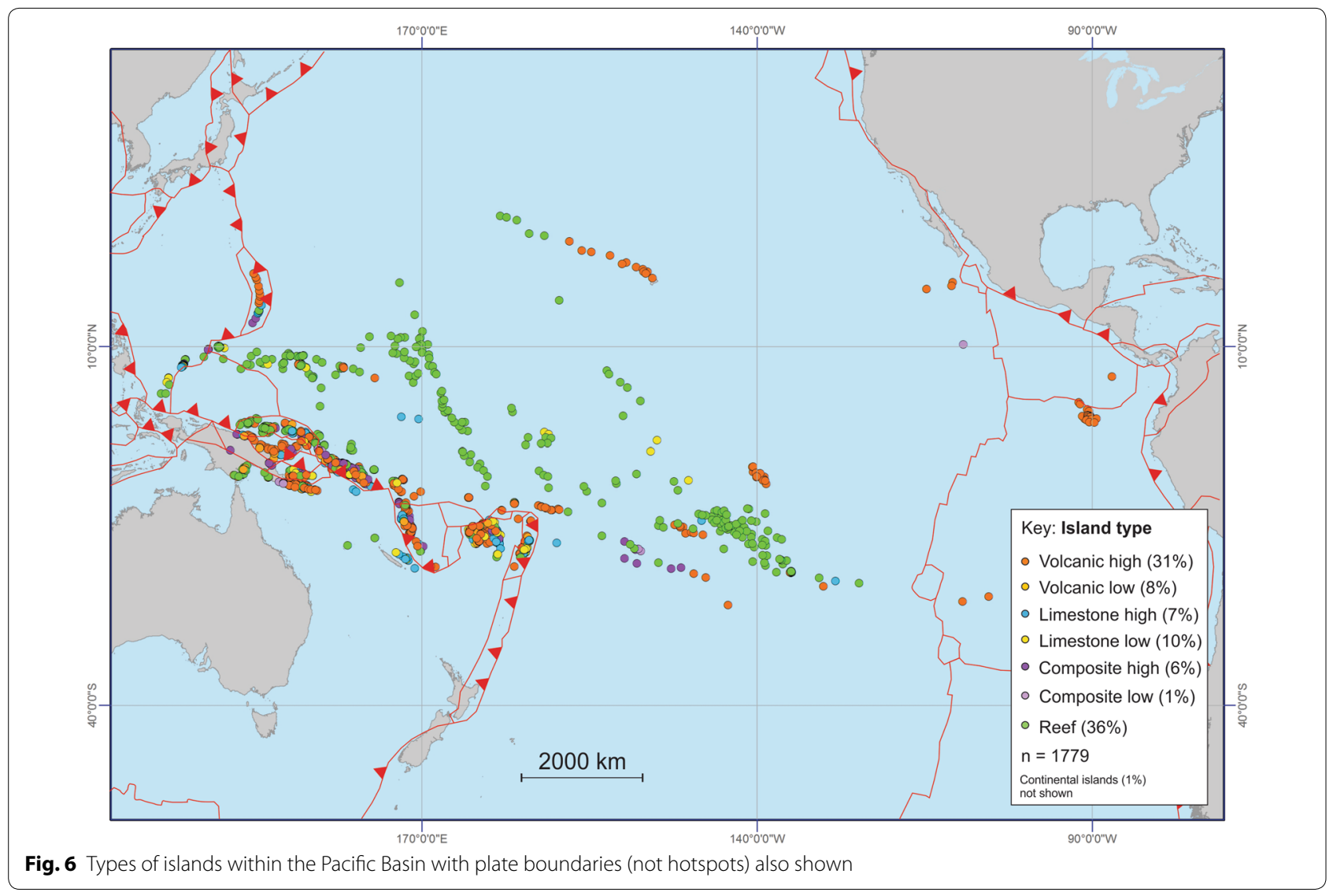

6000 years ago (Grossman et al. 1998), broad reef platforms around the fringes of many islands began developing and came to provide substrates on which islands made of surficial materials might then form. Although strings of such islands (motu) are not counted separately in the database (see above), they nevertheless contribute a substantial number, typically to the population of islands $\leq 10 \mathrm{~km}^{2}$ in area.

The comparative paucity of larger islands can not only be explained by their tendency to be fragmented by sealevel rise (see above) but also by the comparative difficulty of building and maintaining large islands in oceanic settings. Most large islands in the Pacific Basin are anomalous in origin, typically when several distinct islandbuilding processes have come into play at perhaps the same time. By far the largest island in the database, New Guinea $\left(138,958 \mathrm{~km}^{2}\right)$ is an extreme example but nonetheless registers the effects of multiple island-building processes operating alone or simultaneously in various parts at various times above part of the Australian (continental) craton (Davies 2012). The origin of Viti Levu $\left(10,388 \mathrm{~km}^{2}\right)$, the largest island in the Fiji archipelago, is similar, having been created along a succession of island arcs from perhaps $45 \mathrm{Ma}$ until $3 \mathrm{Ma}$ owing to its singular location along the boundary between the Pacific and Indo-Australian Plates (Nunn 1998b). Elsewhere, large islands have been created recently by effusive volcanism, the comparative youth of this explaining why they remain large. Good examples are found close to hotspots near Easter Island, in the Galapagos, Hawaii and parts of French Polynesia. Although the shield volcano on which the island of Savai'i in Samoa is built originated at a hotspot $>300 \mathrm{~km}$ east, its large size $\left(1694 \mathrm{~km}^{2}\right)$ is explainable by younger volcanism associated with rifting along the adjacent Tonga Trench (Keating 1992).

Tectonism also plays a role in the formation of large islands, particularly along island forearcs adjoining convergent plate boundaries where successive upthrusting of reefs and shallow-water sediments can create large limestone islands. Islands like Espiritu Santo $\left(3885 \mathrm{~km}^{2}\right)$ in Vanuatu and Vava'u $\left(260 \mathrm{~km}^{2}\right)$ in Tonga were created in this fashion (Greene and Wong 1988; Nunn 1998b).

The distribution of large islands $\left(>100 \mathrm{~km}^{2}\right)$ in Fig. 3 is closely linked to that of the sites of principal island-forming processes along convergent plate boundaries and near hotspots. From Tonga and Samoa through Fiji, Vanuatu and Solomon islands to Papua New Guinea in the southwest Pacific, there are numerous large islands associated 
with the presence of the long-active convergent boundary between the Pacific and Indo-Australian plates here. Other large islands are dotted along the convergent boundary in the western part of the region (Palau-Guam) but most other large islands are associated with hotspots. These include clusters in the Galapagos and Hawaii as well as ones at Easter Island and in French Polynesia.

The distribution of small islands $\left(\leq 1 \mathrm{~km}^{2}\right)$ is less straightforward to interpret, since these can form in a wide range of situations. What is easier to see in Fig. 3 is that islands in areas away from plate boundaries appear to be mostly intermediate in size $\left(>1-100 \mathrm{~km}^{2}\right)$. This is a residual distribution explainable by the absence of processes that encourage either very large or very small islands to develop in such areas. With volcanic and composite islands, this may be because there are few opportunities for large islands to form here because of the few hotspots where point volcanism dominates; then, as such islands are moved away from the hotspot, they generally subside and are further reduced in size by denudation. The size of reef islands is ultimately limited by that of the reef foundations on which they are built but more commonly by the availability of island-building sediments (McLean and Kench 2015).

\section{Island types}

All the islands in the database were classified by type on the basis of their dominant lithology and their elevation. The distributions of the islands by lithology, (maximum) elevation, and type are discussed in the following three subsections.

\section{Island lithology}

The distribution of the five lithological types recognized for Pacific islands is shown in Fig. 4 with proportions of each type in the key. Most islands are volcanic and their distribution is explained almost entirely by their proximity to places where (subaerial or submarine) volcanism is occurring today. These include intraplate hotspots that produce linear chains of volcanic islands, something readily seen in Fig. 4 for the Hawaii, Marquesas (French Polynesia), Society Islands (French Polynesia), and Samoa hotspots. Linear groups of volcanic islands are also seen along volcanic arcs parallel to convergent plate boundaries in the southwest Pacific from Tonga through Vanuatu to Solomon Islands. Linearity of volcanic island distribution in Fiji and Papua New Guinea is less pronounced because of the multiple island arcs that have contributed to island origin in these large complex archipelagos. There is another clear volcanic island alignment parallel to the adjoining ocean trench in the northern Mariana islands.
In this classification, islands composed of less than $80 \%$ volcanic material (and less than $80 \%$ limestone) are classified as composite, so the distribution of volcanic islands (see above) is a good guide only to recent/ contemporary volcanism. Composite islands of dominantly volcanic composition occur mainly near convergent plate boundaries in the western Pacific, particularly in situations where volcanic islands sensu stricto have been exposed to prolonged tectonic activity that may have caused them to become conjoint with emerged reef (limestone) or other sedimentary formations (reef island) associated with interarc basin compression and uplift. Examples are common in Papua New Guinea and along the relict island arcs in Solomon Islands and Vanuatu that were isolated from proximal volcanism following a switch in subduction direction around 15-11 Ma attributed to the blockage of the ancient Vitiaz Trench by the Ontong Java Plateau (Taylor 2006; Wessel and Kroenke 2000).

Limestone islands are found only in places where uplift has been occurring for prolonged periods. These include intraplate locations where there are localized oceaniclithospheric swells, such as the South Pacific Superswell which accounts for the elevation of atoll islands in the Tuamotu Archipelago (French Polynesia) (McNutt and Fischer 1987). The other major intraplate location in which limestone islands are found is where their underpinning plates are flexing, typically because they are moving toward ocean trenches faster than the rate at which they can be accommodated there; good examples are the Loyalty islands (New Caledonia) (Dickinson 2013). Limestone islands also rise from forearc zones along convergent plate boundaries. In Fig. 4, these are visible in Tonga and Vanuatu; the Lau island group (eastern Fiji), which consists mostly of limestone islands, is a remnant forearc isolated from proximal convergence by opening of the back-arc Lau Basin (Nunn 1998a).

Around $1 \%$ of islands are classified as having a continental lithology (Fig. 4). They are found exclusively in part of New Caledonia where a sliver of continental crust became isolated by Late Cretaceous-Eocene rifting associated with the opening of the Tasman Sea (Cluzell et al. 2012).

More than one-third of the islands in the database are classified as reef islands and these tend to occur more often in intraplate than plate boundary locations (Fig. 4). Most such islands are built on broad reef surfaces at low-tide level and rise only 2-3 m above mean sea level, a result of repeated episodes of large-wave deposition and the leeward migration of deposits beyond the range of normal wave erosion (McLean and Hosking 1991). Although such islands form on fringing reefs, those that endure longest are generally found on more isolated 
reefs, typically barrier or atoll reefs far from the shores of higher islands. Most atoll reefs occur where (a line of) volcanic islands have subsided within the coral seas allowing their former location to continue to be marked by a ring (atoll) reef on which islands (motu) may form. Thus, lines of reef islands rise from submerged volcanic islands in the central western Pacific, from Tuvalu through (western) Kiribati to the Marshall Islands. Other lines of reef islands follow hotspot traces in Micronesia (northwest Pacific) and in French Polynesia (Duncan and McDougall 1976).

\section{Island elevation}

The arbitrary distinction between high and low islands, based on a 30-m elevation above mean sea level, is easy to apply in developing a classification of islands and follows a similar procedure employed to separate younger from older volcanic islands. A finer division of islands based on their elevation is possible from the database, despite potential sources of error and use of a maximum value rather than a measure of central tendency. Hence, for the purposes of discussion, five elevation categories were identified and their distributions are mapped in Fig. 5.

Geologic history provides the context of which island elevation is just one expression. In general, islands would be expected to become lower as they become older. This may be because they become more denuded by subaerial processes and/or because in an oceanic location they are invariably carried from a shallower area where islandforming processes dominate to a deeper place where island-building processes are usually absent. There are exceptions to this but it is an idea with abundant theoretical and empirical support (Menard 1983, 1986).

Island-building processes include primary processessuch as intrusion and extrusion for volcanic (parts of) islands-that may be periodically renewed, perhaps when an older volcanic island becomes the site of younger volcanism, as with Maui (Hawaii) and Savai'i (Samoa) (Bergmanis et al. 2000; Hart et al. 2004). Such rejuvenation invariably results in an increase in maximum elevation both because the lithosphere is locally reheated and because of island mass increase (McNutt and Judge 1990). Examples include some of the Tuamotu islands (French Polynesia) (Pirazzoli and Montaggioni 1988). Lithospheric plate flexure also affects the levels of islands close to convergent plate boundaries in the Pacific, often resulting in their rapid uplift as in the case of Niue and the Loyalty islands (New Caledonia) (Dickinson 2013; Nunn and Britton 2004) and subsequently their rapid submergence as for several seamounts near the bottom of the Tonga-Kermadec Trench (Watts et al. 2010). Yet most of the tectonism that affects Pacific islands occurs on the overriding plate at convergent plate boundaries as a result of the ocean floor being thrust upwards, usually episodically (Ota and Yamaguchi 2004).

Lithology as a measure of resistance to erosion is a major cause of elevation differences in islands of similar age. Comparatively hard-resistant rocks like emerged reef limestones or various igneous rocks allow an island to remain higher longer than when it is composed of lowresistant (even unconsolidated) materials. Denudation is the complement of lithology in this regard because it is principally an expression of the climatic processes that determine the pace of surface lowering of islands in particular places. Islands that experience heavy rainfall, especially during regular storms, will generally be reduced in elevation faster than those located in drier parts of the Pacific; this difference shows up when islands in the western Pacific that are often exposed to tropical cyclones are compared to those in the east that are rarely so. Being an outcome of both lithology and climate, natural vegetation generally increases resistance to erosion although its absence, perhaps after fire, may heighten it. Studies of the Hawaiian islands and Kadavu (Fiji) have linked current island form to these factors (Li 1988; Terry 1999).

The highest islands in the database $(\geq 1000 \mathrm{~m})$ are generally either volcanic or composite and are found in places where uncommonly voluminous eruptions have occurred during the Quaternary; examples come from Hawaii, the Galapagos Islands, the Marquesas and Tahiti (French Polynesia), and Samoa (Fig. 5). The $23 \%$ of high islands $(100-1000 \mathrm{~m})$ are not only clustered in the same places but are also found along the more active parts of plate-convergence zones in the southwest Pacific, pointing to the importance of tectonics in elevating islands in such places.

The lower islands in the database $(<30 \mathrm{~m})$ dominate intraplate locations, illustrating the comparative impotence of most island-building processes here compared to convergent margins as well as the tendency for sinking islands to be preserved as (atoll) reef islands long after their volcanic foundations have been submerged. The (blue-colored) islands in the 5 to $<30 \mathrm{~m}$ category are scattered across the region (Fig. 5) yet concentrated in the region of the South Pacific Superswell in French Polynesia, speaking to the importance of such phenomena in island elevation (McNutt and Fischer 1987).

\section{Island type}

The two most common island types in the Pacific are reef (36 \%) and volcanic high (31 \%) islands; they have quite contrasting distributions (Fig. 6).

Reef islands are concentrated in intraplate locations, most commonly in linear groups that mark lines of submerged volcanic islands above which (atoll/barrier) reef has grown. This situation is exemplified by several linear 
reef-island groups in the Federated States of Micronesia, French Polynesia, Kiribati, Marshall Islands, and Tuvalu as well as the western islands of the Hawaii group (Fig. 6). The large number of reef islands is explainable by their tendency to develop on broad reef surfaces throughout the low-latitude Pacific. Yet this tendency has also been assisted by Late Holocene sea-level fall within the Pacific that has seen some reef surfaces emerge by around $1 \mathrm{~m}$ within the past few thousand years, providing foci for sediment accumulation that has manifestly aided the growth of large reef islands (Dickinson 2004); examples have been described from the Marshall Islands and Tuvalu (McLean and Hosking 1991; Yamaguchi et al. 2009). Yet it is also worth noting that reef islands are generally more vulnerable than other island types to size reduction (and even erasure) under conditions of sealevel rise; projections of this event occurring this century have been made (Dickinson 2009), although there are studies that demonstrate the dynamic nature of reefisland shorelines and emphasizes the point that sea-level rise does not uncritically equate with reef-island 'disappearance' (Webb and Kench 2010; Woodroffe 2008).

Volcanic high islands are the next most common island type in the Pacific. Part of this can be explained by the fact that almost every Pacific island originated as an ocean-floor volcano, so volcanic islands might be expected to be common. Yet the fact that volcanic high islands are so much more numerous than volcanic low islands suggests that where ocean-floor volcanism is sufficiently voluminous and enduring to produce an (emergent) island, it is more often than not able to produce one that reaches more than $30 \mathrm{~m}$ above sea level. Of course, the conical form and structure of many volcanic islands encourage this for 'high' in this classification which refers to maximum elevation; a typical volcanic high island need have only a small fraction of its area exceeding $30 \mathrm{~m}$ for it to be so classified.

Figure 6 shows that volcanic high islands are found in both intraplate and convergent plate boundary situations in the Pacific. Intraplate volcanic high islands appear exclusively associated with hotspots. Examples include Easter Island, the Galapagos, Marquesas and Society groups (French Polynesia), and Samoa; a hotspot explanation for the origin of volcanic high islands in Micronesia (like Pohnpei) appears generally accepted, although other explanations have been suggested (Dixon et al. 1984; Rehman et al. 2013). Volcanic high islands are also numerous around convergent plate boundaries, particularly where active subduction occurred during the Late Quaternary.

Volcanic low islands $(8 \%)$ tend to form near volcanic high islands and their distribution has a similar explanation (see above). Their comparative paucity, perhaps surprising, may also be explained by the general form of volcanic islands, which invariably involves isolated higher parts that resist erosion. It could be argued that it takes a long time and/or unusually comprehensive denudation to reduce a volcanic high to a volcanic low island.

Composite high islands (6\%) are found almost solely along convergent plate boundaries which demonstrates that most are partly volcanic and share similar origins. Convergent plate boundaries are also those places where tectonic forces are greatest in the Pacific and thus islands that have been uplifted are common here. The composite islands in southwest French Polynesia and the southern Cook Islands include the classic makatea islands where a volcanic island with a fringing reef has been uplifted, producing a characteristic composite-lithology landscape (Nunn 1994). The makatea islands of the southern Cooks owe their origin to localized lithospheric flexure associated with the growth of the Rarotonga island volcano (Spencer et al. 1987; Stoddart and Spencer 1987). Composite low islands $(1 \%)$ have a similar distribution to composite high islands.

Contrary to the situation with volcanic islands (see above), limestone low islands are more numerous (10\%) than limestone high islands (7 \%) in the Pacific (Fig. 6). This can be explained in two ways. First, uplift processes are generally unable to raise limestone islands more than $30 \mathrm{~m}$, something that is consistent with the stop-start nature of uplift in many situations; examples where over long time periods bursts of coseismic subsidence are separated by interseismic subsidence have been described from Fiji and Vanuatu (Calmant et al. 1999; Nunn 1995). Second, the form of most limestone islands-characterized by flat (former reef) surfaces rather than peaksmeans that it may be less common to find any part of them elevated above the 30-m threshold.

It is also possible that the majority of limestone islands in the high and low sub-categories have different origins, the former being largely the product of uplift while the latter are mostly a result of sea-level fall. Examination of the distribution of limestone high and low islands (Fig. 6) suggests this may indeed be the case. Limestone low islands in intraplate situations are not generally found near the high ones. Most of the former appear to be relict reef surfaces from pre-Holocene interglaciations; examples come from parts of the Line islands [eastern Kiribati-Schlanger et al. (1984)]. Only a few limestone high islands are found in intraplate situations; they include the islands of Nauru and Niue, which evolved because of lithospheric flexure attributable, respectively, to volcano loading and plate convergence (Hill and Jacobson 1989; Nunn and Britton 2004).

Limestone high islands appear proportionally more numerous along convergent plate boundaries, reflecting 
perhaps the long-term uplift they have experienced. Limestone low islands in such locations tend to be either outliers of larger (higher) islands and/or farther from places where uplift rates are highest. One example of the latter situation is found in the Loyalty Islands group (New Caledonia) which is rising obliquely across a lithospheric flexure; limestone high islands like Maré are near the crest of the flexure, limestone low islands like Beautemps-Beaupré are just beginning to rise up its flank (Dickinson 2013). Another example comes from the (limestone) forearc in Tonga which adjoins the TongaKermadec Trench, at one point of which the (submerged) Louisville Ridge is being subducted, resulting in anomalous forearc uplift above (Dupont and Herzer 1985); limestone islands like Tongatapu rising from the forearc above the Louisville Ridge are high, while others like most in the Ha'apai group are lower because they are not so affected (Nunn 1998b).

\section{Further applications of the classification}

The purpose of this study was to develop a classification of Pacific islands that could be used as a foundation for other, more detailed, studies requiring objective measurement of the diversity of island types within this vast region.

Various possible uses of both the database and classification can be envisaged. At a Pacific-wide scale, it is expected that this classification will be useful to regional planning on topics like exposure to disasters and vulnerability to climate change, particularly sea-level rise. In the past, the development of regional initiatives in such areas has been frustrated by the lack of data from the entire population of Pacific islands as well as by biased measurements of exposure/vulnerability arising from partisan agendas. The classification presented here allows regional planners to recognize these and develop coping/adaptive strategies based on a complete and accurate dataset.

This is not to say of course that the classification presented above can provide a complete solution for every situation. For many regional purposes, it would need elaboration through the addition of classificatory layers. For instance, while vulnerability to long-range tsunamis is crudely a function of island type (especially lithology and elevation), additional data referring to an island's position relative to its neighbors (near and far) as well as the numbers of exposed inhabitants would be needed before it might be usable at a regional (Pacific-wide) scale.

Perhaps more uses of this classification could come at subregional level, where the nature of islands within a certain geographical area could be examined without reference to political boundaries. This would be useful when considering transboundary environmental stressors not only like disasters and various manifestations of climate change but also pollution. Reef islands and low limestone islands are far more vulnerable to water pollution, perhaps like that associated with the 2011 collapse of the Fukushima nuclear power plant that leaked radioactive waters across a great expanse of the northern Pacific Ocean (Johansen et al. 2015).

Another use of this classification at both regional and subregional scales would be to identify commonalities between islands that might not otherwise be readily apparent, particularly to development partners of Pacific Island countries that are accustomed to dealing with political rather than geographical entities. For decades, most regional planning in the Pacific has used countries as a highest-level divisor, thereby ensuring that much research into the characteristics of particular islands and island types to extraneous change would be duplicatedrepeated for nations sharing similar island types. As an alternative to this, the classification developed in this paper allows all islands of particular types (or groups of types) to be readily identified without reference to political boundaries, although these can be superimposed later in any subsequent analysis.

\section{Conclusions}

An earth-science-based classification of islands within the Pacific Basin that is descriptive and readily applicable to a variety of purposes while also capturing essential elements of island diversity has been developed. The classification resulted from preparation of a database describing the location, area, and type of 1779 islands, where island type is determined as a function of the prevailing lithology and maximum elevation of each island. Its essence is that of the scheme adopted by Darwin and others who almost two centuries ago attempted to make sense of the diversity of island types they had encountered in the world's oceans (Darwin 1839; Wallace 1881). Compilation of the database required definition of a island as a discrete landmass within the Pacific Basin comprised of contiguous areas of land $\geq 1$ ha $\left(0.01 \mathrm{~km}^{2}\right)$ above mean high-water level. Short-lived ( $<20$ years) transient islands and reefs lacking islands are not included in the database.

The principal aim of this classification was to assess the spatial diversity of the geologic and geomorphic attributes of islands within the Pacific region. It was intentionally set at a regional scale and based on two attributes: five types of lithology (volcanic, limestone and nonvolcanic sedimentary, composite and continental) and a distinction between high and low islands at elevations greater or less than $30 \mathrm{~m}$ above mean sea level. Classification of island type and the geographic distribution of each attribute were achieved through development of a procedure for classification; identification of data sources; production of maps separately showing the distribution of island locations, areas, lithology, elevation and type; 
interpretation of the mapped distributions in the context of available literature; and discussion of potential future applications of the database and its derived classification. The two key sets of attributes yielded eight island types: volcanic high and low islands; limestone high and low islands, composite high and low islands, reef islands and continental islands. The most common types are reef islands (36 \%) and volcanic high islands (31\%), whereas the least common are composite low islands (1\%). Continental islands, 18 of the 1779 islands examined, are not included in the analysis of the distribution of island types.

It is anticipated the classification will become the basis for more focused investigation of spatial variability in climate and ocean setting, and biological attributes of the Pacific islands. It may also be used in spatial assessments of second-order phenomena associated with the islands, such as their vulnerability to various disasters, coastal erosion or ocean pollution, as well as human populations, built infrastructure, and natural resources.

\section{Additional file}

Additional file 1. The island database developed for this paper.

\section{Authors' contributions}

PN compiled the text and wrote the sections about classification and island types. LK compiled the database and took responsibility for analyses and statistical and graphical outputs and their textual description. IE helped draft all parts of the text. RM conceived the study and helped draft all parts of the text. All authors read and approved the final manuscript.

\section{Author details \\ ${ }^{1}$ University of the Sunshine Coast, Maroochydore, QLD, Australia. ${ }^{2}$ University of New England, Armidale, NSW, Australia. ${ }^{3}$ University of Western Australia, Crawley, WA, Australia. ${ }^{4}$ Damara WA Pty Ltd, Innaloo, WA, Australia. ${ }^{5}$ University of New South Wales, Australian Defence Force Academy, Canberra, Australia.}

\section{Acknowledgements}

This paper derives from a project driven by the Department of Environment in the Australian Government. We thank Lalage Cherry, Cameron Darragh, Kiri Yapp, Sam Hussey-Smith, and Dominic Ransan-Cooper for their support. We also worked at various times with Geoscience Australia and thank their staff for cooperation. We are grateful to Cate Macgregor, Subhashni Taylor, Priyakant Sinha, Roselyn Kumar, Hanieh Saremi, Sahar Alian, and Farzin Shabani at the University of New England for their help with database compilation and analysis.

\section{Competing interests}

The authors declare that they have no competing interests.

Received: 26 November 2015 Accepted: 18 February 2016

Published online: 02 March 2016

\section{References}

Anthony SS (2004) Hydrogeology of selected islands of the Federated States of Micronesia. Dev Sedimentol 54:693-706

Ballmer MD, Ito G, van Hunen J, Tackley PJ (2011) Spatial and temporal variability in Hawaiian hotspot volcanism induced by small-scale convection. Nat Geosci 4(7):457-460. doi:10.1038/ngeo1187
Bergmanis EC, Sinton JM, Trusdell FA (2000) Rejuvenated volcanism along the southwest rift zone, East Maui, Hawai'i. Bull Volc 62(4-5):239-255

Bonatti E, Harrison C, Fisher D, Honnorez J, Schilling JG, Stipp J, Zentilli M (1977) Easter volcanic chain (southeast Pacific): a mantle hot line. J Geophys Res 82(17):2457-2478

Bonvallot J, Dupon J-F, Vigneron E, Gay J-C, Morhange C, Ollier C, Peugniez G, Reitel B, Yon-Cassat F (1993) Atlas de la Polynésie Française. ORSTOM, Paris

Brocher TM (ed) (1985) Geological Investigations of the Northern Melanesian Borderland. Circum-Pacific Council for Energy and Mineral Resources, Houston

Calmant S, Cabioch G, Regnier M, Pillet R, Pelletier B (1999) Cosismic uplifts and interseismic subsidence recorded in corals at Malekula (Vanuatu, southwest Pacific). Comptes Rendus de l'Academie des Sci 328(10):711-716. doi:10.1016/s1251-8050(99)80181-5

Clouard V, Bonneville A (2001) How many Pacific hotspots are fed by deepmantle plumes? Geology 29(8):695-698

Cluzell D, Maurizot P, Collot J, Sevin B (2012) An outline of the geology of New Caledonia; from Permian-Mesozoic southeast Gondwanaland active margin to Cenozoic obduction and supergene evolution. Episodes 35(1):72-86

Coleman P (1970) Geology of the Solomon and New Hebrides Islands, as part of the Melanesian re-entrant, southwest Pacific. Pac Sci 24:289-314

Connell J (2010) Pacific islands in the global economy: paradoxes of migration and culture. Singap J Trop Geogr 31(1):115-129. doi:10.1111/j.1467-9493.2010.00387.x

Connell J (2011) Elephants in the Pacific? Pacific urbanisation and its discontents. Asia Pac Viewp 52(2):121-135

Crocombe R (2001) The South Pacific. University of the South Pacific, Suva

Crook KA, Taylor B (1994) Structure and Quaternary tectonic history of the Woodlark triple junction region, Solomon islands. Mar Geophys Res 16(1):65-89

Dahl AL (1980) Regional ecosystems survey of the South Pacific area. Technical paper 179. South Pacific Commission, Noumea

Dana JD (1875) Corals and coral islands, 2nd edn. Sampson Low, London

Darwin C (1839) Journal of researches into the geology and natural history of the various countries visited by HMS Beagle: under the command of captain FitzRoy, RN, from 1832 to 1836, vol 14. Henry Colburn, London

Davies HL (2012) The geology of New Guinea-the cordilleran margin of the Australian continent. Episodes 35(1):87-102

Davis WM (1920) The islands and coral reefs of Fiji. Geogr J. 55:34-45, 200-220, $377-388$

Derrick RA (1957) The Fiji islands: a geographical handbook, Revised edition. Government Press, Suva

Dickinson WR (2001) Paleoshoreline record of relative Holocene sea levels on Pacific islands. Earth Sci Rev 55(3):191-234

Dickinson WR (2004) Impacts of eustasy and hydro-isostasy on the evolution and landforms of Pacific atolls. Palaeogeogr Palaeoclimatol Palaeoecol 213(3-4):251-269. doi:10.1016/j.palaeo.2004.07.012

Dickinson WR (2009) Pacific Atoll living: how long already and until when? GSA Today 19(3):4-10. doi:10.1130/gsatg35a.1

Dickinson WR (2013) Control of paleoshorelines by trench forebulge uplift, Loyalty islands. Quat Res 80(1):125-137

Dixon TH, Batiza R, Futa K, Martin D (1984) Petrochemistry, age and isotopic composition of alkali basalts from Ponape island, western Pacific. Chem Geol 43(1-2):1-28

Dow DB (1977) A geological synthesis of Papua New Guinea, vol 201. Australian Government Publishing Service

Duncan RA, McDougall I (1976) Linear volcanism in French Polynesia. J Volcanol Geoth Res 1:198-227

Duncan RA, Richards M (1991) Hotspots, mantle plumes, flood basalts, and true polar wander. Rev Geophys 29(1):31-50

Dupont J, Herzer RH (1985) Effect of subduction of the Louisville Ridge on the structure and morphology of the Tonga arc. In: Scholl DW, Vallier TL (eds) Geology and offshore resources of Pacific island Arcs-Tonga region. Circum-Pacific Council for Energy and Mineral Resources, Houston, pp 323-332

Ellison JC (2009) Wetlands of the Pacific island region. Wetlands Ecol Manage 17(3):169-206

Fairbridge RW (1968) Islands. In: Fairbridge RW (ed) Encyclopedia of geomorphology. Reinhold, New York, pp 568-576 
Frisch W, Meschede M, Blakey R (2011) Plate Tectonics. Springer, Berlin

Gillespie RG, Clague DA (2009) Encyclopedia of Islands. University of California Press, Berkeley

Greene HG, Wong FL (eds) (1988) Geology and offshore resources of Pacific island Arcs - Vanuatu region. Circum-Pacific Council for Energy and Mineral Resources, Houston

Grigor'yev GN (1971) A genetic classification of islands. Soviet Geogr 12:585-592

Grossman EE, Fletcher CH III, Richmond BM (1998) The Holocene sea-level highstand in the equatorial Pacific: analysis of the insular paleosea-level database. Coral Reefs 17(3):309-327. doi:10.1007/s003380050132

Hart S, Coetzee M, Workman R, Blusztajn J, Johnson K, Sinton J, Steinberger B, Hawkins J (2004) Genesis of the western Samoa seamount province: age, geochemical fingerprint and tectonics. Earth Planet Sci Lett 227(1):37-56

Herzberg C (2011) Identification of source lithology in the Hawaiian and Canary islands: implications for origins. J Petrol 52(1):113-146. doi:10.1093/petrology/egq075

Hill PJ, Jacobson G (1989) Structure and evolution of Nauru island, central Pacific ocean. Aust J Earth Sci 36(3):365-381. doi:10.1080/08120098908729495

Husson L, Conrad CP (2012) On the location of hotspots in the framework of mantle convection. Geophys Res Lett 39:L17304

Johansen MP, Ruedig E, Tagami K, Uchida S, Higley K, Beresford NA (2015) Radiological dose rates to marine fish from the Fukushima Daiichi accident: the first three years across the North Pacific. Environ Sci Technol 49(3):1277-1285. doi:10.1021/es505064d

Jost C (ed) (1998) The French-speaking Pacific. Boombana, Mount Nebo

Kaplin PA (1981) Relief, age, and types of oceanic island. NZ Geogr $27: 3-12$

Karolle BG (1993) Atlas of Micronesia. Bess Press, Honolulu

Keating BH (1992) The geology of the Samoan Islands. In: Keating BH, Bolton BR (eds) Geology and offshore resources of the central Pacific basin. Circum-Pacific council for energy and mineral resources, earth science series, vol 14. Springer, New York, pp 127-178

Keating BH, Bolton BR (eds) (1992) Geology and offshore mineral resources of the central Pacific basin. Springer, New York

King SD, Adam C (2014) Hotspot swells revisited. Phys Earth Planet Inter 235:66-83. doi:10.1016/j.pepi.2014.07.006

Köppen W (1936) Das geographisca System der Klimate. In: Köppen W, Geige $\mathrm{G}$ (eds) Handbuch der Klimatologie. Gebrüder Borntraeger, Berlin

Lafoy Y, Géli L, Klingelhoefer F, Vially R, Sichler B, Nouzé H (2005) Discovery of continental stretching and oceanic spreading in the Tasman Sea. Eos Trans Am Geophys Union 86(10):101-105

Langdon R (1978) American whalers and traders in the Pacific: a guide to records on microfilm. Pacific Manuscripts Bureau, Canberra

Li Y-H (1988) Denudation rates of the Hawaiian islands by rivers and groundwaters. Pac Sci 42(3-4):253-266

Lobban CS, Schefter M (1997) Tropical Pacific island environments. University of Guam Press, Guam

Macdonald GA, Abbott AT, Peterson FL (1983) Volcanoes in the sea: the geology of Hawaii. University of Hawaii Press, Honolulu

McBirney AR, Williams H, Aoki K (1969) Geology and petrology of the Galápagos islands, vol Memoir 118. Geological Society of America, Boulder

McLean RF, Hosking PL (1991) Geomorphology of reef islands and atoll motu in Tuvalu. South Pac J Nat Sci 11:167-189

McLean R, Kench P (2015) Destruction or persistence of coral atoll islands in the face of 20th and 21st century sea-level rise? Wiley interdisciplinary reviews-climate change 6(5):445-463. doi:10.1002/wcc.350

McNutt MK, Fischer KM (1987) The South Pacific Superswell. In: Keating BH, Fryer P, Batiza R, Boehlert GW (eds) Seamounts, islands, and Atolls. American Geophysical Union, Washington, pp 25-34. doi:10.1029/ GM043p0025

McNutt MK, Judge AV (1990) The superswell and mantle dynamics beneath the South Pacific. Science 248(4958):969-975

Menard HW (1983) Insular erosion, isostasy, and subsidence. Science 220(4600):913-918. doi:10.1126/science.220.4600.913

Menard HW (1986) Islands. Scientific American, New York

Motteler LS (2006) Pacific island names: a map and name guide to the new Pacific, vol 34. Miscellaneous Publications, 2nd edn. B.P. Bishop Museum Press, Honolulu
Mueller-Dombois D, Fosberg FR (1998) Vegetation of the tropical Pacific islands. Springer, New York

Neall VE, Trewick SA (2008) The age and origin of the Pacific islands: a geological overview. Philos Trans R Soc B Biol Sci 363(1508):3293-3308. doi:10.1098/rstb.2008.0119

Nunn PD (1994) Oceanic islands. Blackwell, Oxford

Nunn PD (1995) Holocene tectonic histories for five islands in the southcentral Lau group, South Pacific. Holocene 5(2):160-171

Nunn PD (1998a) Late Quaternary tectonic change on the islands of the northern Lau-Colville Ridge, southwest Pacific. In: Stewart IS, Vita-Finzi C (eds) Coastal tectonics. Special Publications, vol 146. Geological Society of London, London, pp 269-278

Nunn PD (1998b) Pacific island landscapes: landscape and geological development of southwest Pacific islands, especially Fiji, Samoa and Tonga. Institute of Pacific studies, The University of the South Pacific, Suva

Nunn PD (1999) Environmental change in the Pacific basin: chronologies, causes, consequences. Wiley, New York

Nunn PD (2013) The end of the Pacific? effects of sea level rise on Pacific island livelihoods. Singap J Trop Geogr 34(2):143-171. doi:10.1111/sjtg.12021

Nunn PD, Britton JMR (2004) The long-term evolution of Niue Island. In: Terry J, Murray W (eds) Geographical perspectives on the rock of Polynesia. INSULA, Paris, pp 31-74

Oakley A, Taylor B, Moore G, Goodliffe A (2009) Sedimentary, volcanic, and tectonic processes of the central Mariana Arc: Mariana Trough back-arc basin formation and the West Mariana Ridge. Geochem Geophys Geosystems 10 (8):Q08X07. doi:10.1029/2008GC002312

Oba T, Irino T (2012) Sea level at the last glacial maximum, constrained by oxygen isotopic curves of planktonic foraminifera in the Japan Sea. $J$ Quat Sci 27(9):941-947. doi:10.1002/jqs.2585

Ota Y, Yamaguchi M (2004) Holocene coastal uplift in the western Pacific Rim in the context of late Quaternary uplift. Quat Int 120(1):105-117

Petterson M, Babbs T, Neal C, Mahoney J, Saunders A, Duncan R, Tolia D, Magu R, Qopoto C, Mahoa H (1999) Geological-tectonic framework of Solomon islands, SW Pacific: crustal accretion and growth within an intra-oceanic setting. Tectonophysics 301(1):35-60

Pirazzoli P, Montaggioni L (1988) Holocene sea-level changes in French Polynesia. Palaeogeogr Palaeoclimatol Palaeoecol 68(2):153-175

Prueher LM, Rea DK (2001) Tephrochronology of the Kamchatka-Kurile and Aleutian arcs: evidence for volcanic episodicity. J Volcanol Geoth Res 106(1-2):67-84. doi:10.1016/s0377-0273(00)00266-3

Ramalho RS, Quartau R, Trenhaile AS, Mitchell NC, Woodroffe CD, Ávila SP (2013) Coastal evolution on volcanic oceanic islands: a complex interplay between volcanism, erosion, sedimentation, sea-level change and biogenic production. Earth Sci Rev 127:140-170

Rapaport M (ed) (2013) The Pacific islands: environment and society. Revised edition. University of Hawai'i Press, Honolulu

Ray JS, Mahoney JJ, Duncan RA, Ray J, Wessel P, Naar DF (2012) Chronology and geochemistry of lavas from the Nazca Ridge and easter Seamoun Chain: an 30 Myr hotspot record. J Petrol 53(7):1417-1448

Rehman HU, Nakaya H, Kawai K (2013) Geological origin of the volcanic islands of the Caroline Group in the Federated States of Micronesia, Western Pacific. South Pac Stud 33(2):101-118

Richardson SD, Richardson J (1986) Agroforestry and the Pacific Islands. Environment and Policy Institute, East-West Center, Honolulu

Schlanger SO, Garcia MO, Keating BH, Naughton JJ, Sager WW, Haggerty JA, Philpotts JA, Duncan RA (1984) Geology and geochronology of the Line islands. J Geophys Res 89(NB13):1261-1272. doi:10.1029/ JB089iB13p11261

Scholl DW, Vallier TL (eds) (1985) Geology and Offshore Resources of Pacific Island Arcs-Tonga Region. Circum-Pacific Council for Energy and Mineral Resources, Houston

Scott GAJ, Rotondo GM (1983) A model to explain the differences between Pacific plate island-atoll types. Coral Reefs 1:139-150

Silver E, Day S, Ward S, Hoffmann G, Llanes P, Driscoll N, Appelgate B, Saunders $S$ (2009) Volcano collapse and tsunami generation in the Bismarck Volcanic Arc, Papua New Guinea. J Volcanol Geoth Res 186(3):210-222

Sleep NH (1990) Hotspots and mantle plumes: some phenomenology. J Geophys Res 95:6715-6936

Smith DK, Schouten H, Montesi L, Zhu WL (2013) The recent history of the Galapagos triple junction preserved on the Pacific plate. Earth Planet Sci Lett 371:6-15. doi:10.1016/j.epsl.2013.04.018 
Soluri EA, Woodson VA (1990) World vector shoreline. Int Hydrogr Rev 67(1):27-35

Sorbadere F, Schiano P, Métrich N, Bertagnini A (2013) Small-scale coexistence of island-arc-and enriched-MORB-type basalts in the central Vanuatu arc. Contrib Miner Petrol 166(5):1305-1321

Spencer T, Stoddart DR, Woodroffe CD (1987) Island uplift and lithospheric flexure: observations and cautions from the South Pacific. Zeitschrift für Geomorphologie Supplementband 63:87-102

Stoddart DR, Spencer T (1987) Rurutu reconsidered: the development of makatea topography in the Austral islands. Atoll Res Bull 297:1-19

Stoddart DR, McLean RF, Hopley D (1978) Geomorphology of reef islands, northern great Barrier Reef. Philos Trans R Soc Lond Se B Biol Sci 284:149-159

Taylor B (2006) The single largest oceanic plateau: Ontong Java-ManihikiHikurangi. Earth Planet Sci Lett 241(3):372-380

Terry JP (1999) Kadavu island, Fiji: fluvial studies of a volcanic island in the humid tropical South Pacific. Singap J Trop Geogr 20(1):86-98

Tian L, Castillo PR, Hilton DR, Hawkins JW, Hanan BB, Pietruszka AJ (2011) Major and trace element and Sr-Nd isotope signatures of the northern Lau basin lavas: implications for the composition and dynamics of the backarc basin mantle. J Geophys Res 116(B11):B11201

Tracey JI, Schlanger S, Stark J, Doan D, May H (1964) General geology of Guam. US Government Printing Office

Vacher LHL, Quinn TM (eds) (1997) Geology and hydrogeology of carbonate islands. Developments in Sedimentology 54. Elsevier, Amsterdam

Wallace AR (1881) Island life or, the phenomena and causes of insular faunas and floras including a revision and attempted solution of the problem of geological climates. Harper, New York
Walsh RPD (1982) The influence of climate, lithology, and time drainage density and relief development in the volcanic terrain of the Windward Islands. In: Douglas I, Spencer T (eds) Environmental change and tropical geomorphology. Allen and Unwin, London, pp 93-122

Ward RG (1989) Earth's empty quarter - the Pacific islands in a Pacific century. Geogr J 155:235-246. doi:10.2307/635065

Watts AB, Koppers AA, Robinson DP (2010) Seamount subduction and earthquakes. Oceanography 23(1):166-173

Webb AP, Kench PS (2010) The dynamic response of reef islands to sealevel rise: evidence from multi-decadal analysis of island change in the Central Pacific. Glob Planet Chang 72(3):234-246. doi:10.1016/j. gloplacha.2010.05.003

Wessel P, Kroenke LW (2000) Ontong Java Plateau and late Neogene changes in Pacific plate motion. J Geophys Res Solid Earth 105(B12):2825528277. doi:10.1029/2000jb900290

Wessel P, Kroenke LW (2008) Pacific absolute plate motion since 145 Ma: an assessment of the fixed hot spot hypothesis. J Geophys Res 113(B6):B06101

Wiens HJ (1962) Atoll environment and ecology. Yale University Press, New Haven

Wood BL (1967) Geology of the Cook Islands. NZ J Geol Geophys 10(6):1429-1445

Woodroffe CD (2008) Reef-island topography and the vulnerability of atolls to sea-level rise. Glob Planet Chang 62(1-2):77-96. doi:10.1016/j. gloplacha.2007.11.001

Yamaguchi T, Kayanne H, Yamano H (2009) Archaeological investigation of the landscape history of an Oceanic atoll: Majuro, Marshall Islands. Pac Sci 63(4):537-565. doi:10.2984/049.063.0405

\section{Submit your manuscript to a SpringerOpen ${ }^{\odot}$ journal and benefit from:}

- Convenient online submission

- Rigorous peer review

- Immediate publication on acceptance

- Open access: articles freely available online

- High visibility within the field

- Retaining the copyright to your article

Submit your next manuscript at $>$ springeropen.com 